estimation of sugar in small quantities of blood. A dozen workers were on the track. Banting and Best coming in late, but with the freshness and ardour of youth, arrived first.

I believe that NATURE has urged the desirability of a sum of money being set aside by Parliament for the reward of 'discovery:' I contend that any such sum should rather be used as consolation prizes for the many able scientific workers who have never made a discovery.

Discovery brings its own reward. Not only is there the joy of being first on a virgin peak-a joy that every mountaineer hopes to experience at least once in his lifetime-but, if the discovery is of a nature to be appreciated by the public, it brings in its train Royal medals, K.C.B.'s, Nobel prizes, and academic distinctions of all sorts, not to mention the plaudits of the daily press.

The Medical Research Council has no need to concern itself with 'discoveries.' All it has to do is to ensure that the growing tree of knowledge is dug round and pruned, dunged, and watered. The fruit will come in due season, and will fall to the lot of some one who may or may not have been assiduous in the labour of cultivation. The Report of the Counci shows that this, its function, is being wisely and diligently carried out; and we servants in the House of Science cannot but approve of its efforts to facilitate our work.

University College, W.C.I, April I2.

Note.-I see that, in this week's NATURE, you have the distinguished support of Sir Ronald Ross in what I venture to regard as your heresy. Rewards such as he advocates might, like charity, do much good to the giver; they would not, I think, influence in the slightest degree the output of 'discovery.'

April 19.

E. H. S.

Prof. Starling considers that a body like the Medical Research Council has to concern itself only with digging round, pruning, manuring and watering the plant of knowledge. It depends a great deal upon the person who carries out these operations. Instead of ripe fruit the result may be a lot of stray leaves. We cordially agree that discoveries in science are usually the end stage of many trials by many people, but the one who ultimately succeeds where hundreds have failed is surely entitled to a good deal of credit. THE WRITER OF THE ARTICLE.

\section{Monazite Sands and other Sources of Thoria.}

MAY I solicit space for a rejoinder to "The Writer of the Article," who replied to my letter published in NATURE of February I6. The explanation given does not satisfy me. The Imperial Institute discovered thorium in some samples sent from Ceylon. I am not trying to minimise the importance of this discovery, but I object to the statement that " the discovery of the monazite sands of Ceylon has destroyed the former German monopoly based on Brazilian material." According to the Imperial Mineral Resources Bureau's monograph, Ceylon produced monazite concentrates in commercial quantities for the first time in I9I8. These quantities, as the table published with my first letter will show, were too small to make the slightest difference to the general position. In the years I905, 1906, and $x 907$, thorianite was exported from Ceylon to the extent of approximately 9 tons, $2 \frac{1}{2}$ tons, and $\frac{1}{2}$ ton respectively. One hundredweight of thorite was exported in 1905 .
The total production of thorium-bearing minerals from Ceylon up to and including I92I comes to 208 tons. Within the same period India produced 76 times this total. The German monopoly was destroyed by the Government of India's action during the War in refusing to allow foreigners to work mineral concessions in India.

The Imperial Institute was instrumental in directing attention to the possibility of finding monazite in India, but to take all the credit not only for its discovery, but also for the breaking up of the German monopoly in thorium-bearing minerals, seems to me an extravagant attitude. Valuable deposits of oil shale have recently been discovered in Somersetshire. Had I the same temperament as "The Writer of the Article," I might write to the Geological Survey of Great Britain suggesting that they should try the Lias deposits of the Midlands and claim the credit for any subsequent discovery of oil shales in that part of England. E. H. PAscoE.

Geological Survey of India, Calcutta, March I3.

Apparently Dr. Pascoe would not dissent from the statement that the Ceylon discovery, of which the influence does not admit of simple statistical proof or disproof, struck the first blow at the German monopoly. The term " monazite sand " was used, in accordance with commercial practice, to include other minerals yielding thorium.

The Writer of the Article.

\section{Philosophical Magazine, 1914-1923.}

I would like to direct attention to the case of Prof. Chwolson, of Petrograd, the author of the great text-book on physics. He is now working on the new edition of the last volume, and for consultation purposes is in urgent need of the Philosophical Magazine, I9I4-I923.

Prof. Chwolson (who is seventy-one years of age) finds it impossible to get copies of the magazine in Petrograd, and is quite unable to purchase it. I should be very grateful, therefore, if any readers of NATURE could see their way to let me have the above for despatch to Petrograd. Possibly my Committee might be prepared to pay a small sum, if any possessor of the magazine was unable to present it

B. M. HEADICAR,

Universities' Library for Central Europe, Hon. Secretary.

London School of Economics, Clare Market,

London, W.C.2, April 3.

\section{Sir William Grookes.}

THERE is an error in my "Iife of Sir William Crookes" which I should like to rectify. I stated that the disagreement between Crookes and the late Sir James Dewar over a method of producing colloidal silver led to the bankruptcy of Crookes's eldest son Henry, who had discovered the method while working under the direction of Sir James Dewar.

I now find that there was no such bankruptcy, but that Henry Crookes voluntarily resigned his work at the laboratory and set up independently, with considerable eventual success.

In justice to the three men, who are now dead, I should be glad if you could publish this correction in your journal. E. E. Fournier D'Albe.

The Hermitage, Portsmouth Road, Kingston-on-Thames, April 13.

$$
\text { NO. } 2843 \text {, vOL. I I } 3 \text { ] }
$$

